\title{
How pestiferous are maize weevil Sitophilus zeamais (Motschulsky, 1855) (Coleoptera: Curculionidae) and rust-red flour beetle Tribolium castaneum (Herbst, 1797) (Coleoptera: Tenebrionidae) against dried okra Abelmoschus esculentus (L.) Moench (Malvales: Malvaceae) fruit?
}

\section{Oladele A. Olaniran, Samuel A. Babarinde*, Fatai O. Alao, Adetayo D. Adeleye, Afeez Ige, Johnson A. Okunlola}

Department of Crop and Environmental Protection. Ladoke Akintola University of Technology. Ogbomoso. Nigeria. *Email: sababarinde@lautech.edu.ng.

Abstract. Okra Abelmoschus esculentus (L.) Moench (Malvales: Malvaceae) is a major fruit vegetable consumed in either fresh or dried form in Africa. As part of our efforts to identify the pestiferous species attacking dried fruits, a laboratory experiment was conducted to investigate the damage potentials of Sitophilus zeamais (Motschulsky, 1855) (Coleoptera: Curculionidae) and Tribolium castaneum (Herbst, 1797) (Coleoptera: Tenebrionidae) against dried okra. Three levels of infestations $(5,10$ and 20 adults of each insect) on dried okra and okra without insect infestation, which served as control were kept under ambient conditions. The experiment was laid out in completely randomized design and replicated thrice. Data were collected on percentage insect mortality, okra weight loss and proximate composition. Percentage mortality increased with storage duration, while weight loss was significantly affected by insect infestation levels and ranged from $0.04 \%-0.18 \%, 0.07 \%$ $0.21 \%, 0.08 \%-0.22 \%, 0.07 \%-022 \%, 0.11 \%-0.22 \%$ and $0.12 \%-$ $0.23 \%$ for $1,2,3,4,5$ and 6 weeks after infestation, respectively. Crude fibre significantly increased with insect infestation (13.98\%-14.62\% for the infested okra compared with $9.12 \%$ $13.63 \%$ in the control), while other proximate components were not significantly affected. The results show that the two species pose no serious threat to intact dried okra, in the short term, but long term multiple generation infestation of dried okra by the insects may cause greater damage.

Keyword: Dried okra fruit; Stored product pests; Weight loss; Proximate composition; Mortality.

Resumo. Quão danosos são o gorgojo-do-milho Sitophilus zeamais (Motschulsky, 1855) (Coleoptera: Curculionidae) e o besouro castanho Tribolium castaneum (Herbst, 1797) (Coleoptera: Tenebrionidae) contra o fruto do quiabo
Received:

Dec. 05, 2017

Accepted:

Feb. 13, 2018

Released:

Apr. 30, 2018

Open access

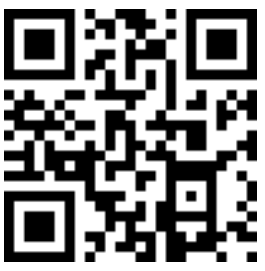

ORCID

(D) 0000-0003-0278-4454 Oladele A. Olaniran

(1) 0000-0002-0861-503X Samuel A. Babarinde

(D) 0000-0001-9205-4265 Fatai O. Alao

(D) 0000-0002-8044-815X Adetayo D. Adeleye

(D) 0000-0002-5611-917X Afeez Ige

(D) 0000-0003-0395-7484 Johnson A. Okunlola 
Abelmoschus esculentus (L.) Moench (Malvales: Malvaceae) seco? O quiabo Abelmoschus esculentus (L.) Moench (Malvales: Malvaceae) é um dos principais vegetais consumidos em forma fresca ou seca na África. Como parte de nossos esforços para identificar as espécies que atacam frutos secos, um experimento de laboratório foi conduzido para investigar os potenciais danos de Sitophilus zeamais (Motschulsky, 1855) (Coleoptera: Curculionidae) e Tribolium castaneum (Herbst, 1797) (Coleoptera: Tenebrionidae) contra o quiabo seco. Três níveis de infestações (5, 10 e 20 adultos de cada inseto) em quiabo seco e quiabo sem infestação de insetos, que serviram de controle, foram mantidos em condições ambientais. 0 experimento foi apresentado em delineamento inteiramente casualizado e repetido três vezes. Os dados foram coletados sobre porcentagem de mortalidade por insetos, perda de peso do quiabo e composição centesimal. A mortalidade percentual aumentou com a duração do armazenamento, enquanto a perda de peso foi significativamente afetada pelos níveis de infestação de insetos e variou de $0,04 \%-0,18 \%, 0,07 \%-0,21 \%, 0,08 \%-0,22 \%, 0,07 \%$ $022 \%, 0,11 \%-0,22 \%$ e $0,12 \%-0,23 \%$ para $1,2,3,4,5$ e 6 semanas após a infestação, respectivamente. A fibra bruta aumentou significativamente com a infestação de insetos (13,98\%-14,62\% para o quiabo infestado, em comparação com 9,12\%-13,63\% no controle), enquanto outros componentes centesimais não foram significativamente afetados. Os resultados mostram que as duas espécies não representam uma séria ameaça para o quiabo seco intacto, em curto prazo, mas a infestação por longo prazo de gerações múltiplas de quiabo seco pelos insetos pode causar maiores danos.

Palavras-chave: Quiabo; Peste de produtos estocados; Perda de peso; Composição centesimal; Mortalidade.

\section{Introduction}

Okra Abelmoschus esculentus (L.) Moench (Malvales: Malvaceae) is an important vegetable in Nigeria and many countries of the world. It is a prominent fruit and leafy vegetable grown for domestic consumption of the highly nutritious immature leaves and fruits in Nigeria (Farinde et al., 2007). Okra fruit contains vitamins $\mathrm{A}, \mathrm{B}, \mathrm{C}$ minerals, iron, iodine, proteins and carbohydrates but it is low in sodium, saturated fat and cholesterol (Lamont Jr., 1999; Owolarafe and Shotonde, 2004), and plays a vital role in human diet. Whole, fresh okra fruits also make excellent pickles. It could also be fried to reduce its slippery characteristics. Okra mucilage is used for glace paper production and confectionary (Akinyele and Temikotan, 2007). It has medical application as a plasma replacement or blood volume expander (Adetuyi et al., 2008; Kumar et al., 2010). Okra is being cultivated by farmers in Africa either as sole crop or mixed with other arable crops like maize, cowpea or yam. It can be grown on a wide range of soil but prefers well-drained sandy loam with $\mathrm{pH}$ 6-7 and a high content of organic matter (Akanbi et al., 2010; Akande et al., 2010).

One of the limiting factors in okra production is the damage caused by insect pests. The incidence of insect pests is observed in all phonologies of the crop and the insect pests that attack it are also common among other members of the 
Family Malvaceae. Some of the insect pests that attack okra include Podagrica species, Bamesia species and aphids, Zonocerus variegatus, okra red mite, cotton strainer, cotton bollworm and cotton shield bug. They attack the crop and cause significant yield reduction (Kumar et al., 2010; Ekoja et al., 2012). During the time of surplus production, rural famers usually process freshly harvested okra fruits into dried form in order to prevent loss to postharvest decay or the option of selling their produce at ridiculously cheap prices. Secondly, some rural dwellers dry okra in order to achieve value chain varieties or change of taste. The dried fruit can then be stored for longer period, without the threat of microbial degradation once the moisture content is kept about $12 \%$. Insects damage stored agricultural produce and also create conditions that allow secondary infestation by other pests and deterioration by microorganisms, primarily fungi. Their infestation can initiate progressive damage, leading to losses in nutrition, organoleptic and aesthetic quality as well as weight loss. In our recent observations in the laboratory, we have established that the host spectrum of some stored product coleoptera is increasing from the conventionally known grains to some non-grain hosts. For instance, rust-red flour beetle Tribolium castaneum (Herbst, 1797) (Coleoptera: Tenebrionidae) and Khapra beetle Trogoderma granarium Everts, 1898 (Coleoptera: Dermestidae), have been reported to be pestiferous against plantain chips (Babarinde et al., 2010a,b); while Odeyemi et al. (2005) reported the infestation of biscuit by $T$. castaneum. Cigarette beetle Lasioderma serricorne (Fabricius, 1792) (Coleoptera: Anobiidae) was reported to infest various crops including dried vegetables (Babarinde et al. 2008a); while maize weevil S. zeamais was reported to be pestiferous against tuberous crops and other non-grain produce (Babarinde et al., 2008b, 2013b). Besides whole and intact grains, both $S$. zeamais and $T$. castaneum have been reported to be pestiferous against pastas (Pungitore et al., 2005; Trematerra, 2009; Babarinde et al., 2013a; Tremattera and Savoldelli, 2014).

In many developing countries, different stored products are usually stored in the same storage facilities by resource-poor farmers, which can heighten the tendency of crossinfestation by insects. Hence, it is not unlikely to find different insect pests in hosts that are not originally established to be their food. Therefore, the objectives of this study were (a) to evaluate the damage potential of two insect pests S.zeamais and T. castaneum on dried okra fruits (b) to evaluate the impact of the pests' infestation on the proximate composition of the infested fruits.

\section{Materials and methods}

\section{Research location}

The study was carried out in the Department of Crop and Environmental Protection Laboratory, Ladoke Akintola University of Technology Ogbomoso, Nigeria.

\section{materials}

\section{Procurement of experimental}

Adult $S$. zeamais were obtained from heavily infested maize sample and adult $T$. castaneum was obtained from old poultry feed. The two insect species were separately reared on maize grain and millet flour, respectively in glass jars covered with muslin cloth to allow aeration and prevent escape of the insects as well as entry of other insect like predators as described by (Babarinde et al., 2008a). The cultures were maintained under ambient conditions in the laboratory. The process of okra fruit drying is shown in the Figure 1. 


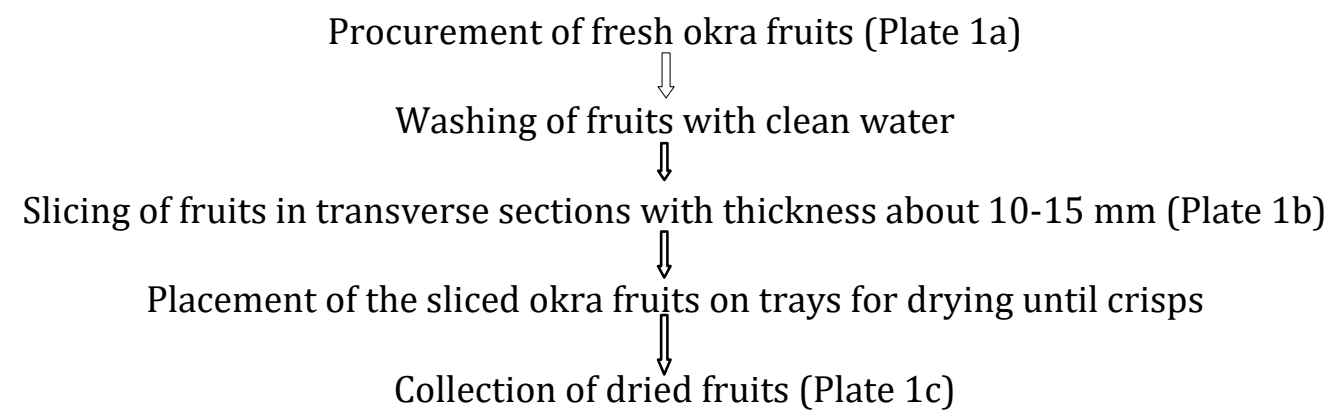

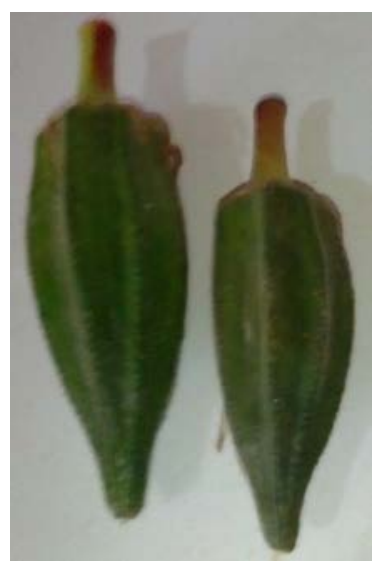

Plate 1a. Fresh okra fruits.

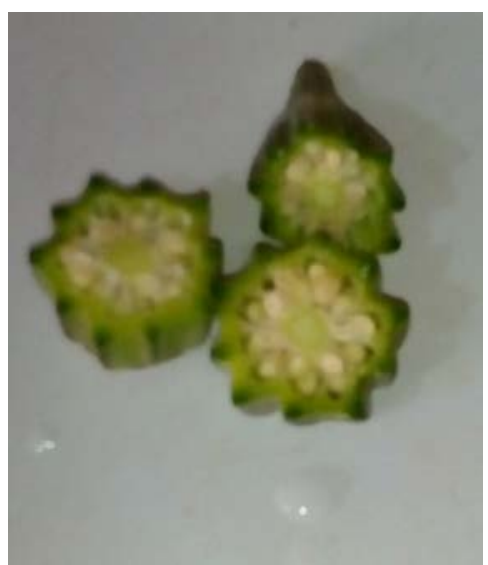

Plate 1b. Sliced okra fruit prepared for drying.

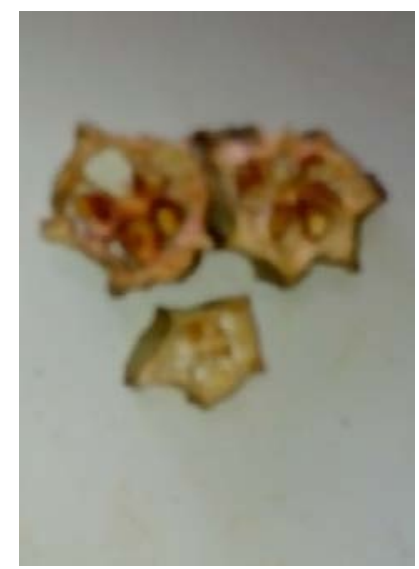

Plate 1c. Dried okra fruit.

Figure 1. The process of okra fruit drying.

\section{Entomological procedures and proximate analysis of stored okra fruit}

Ten grams of dried okra fruit were weighed into $150 \mathrm{~mL}$ capacity glass jars. Three levels $(5,10$ and 20 mixed-sex adults) of $T$. castaneum and $S$. zeamais infestation were separately introduced into the dried okra. Another $10 \mathrm{~g}$ dried okra without any insect served as control. The experiment was replicated thrice. Data were collected on percentage mortality and weight loss of dried okra fruit at 1-6 weeks after infestation (WAI). The samples were analysed for moisture, protein, fat, ash, fibre and nitrogen free extract by the methods of AOAC (2003) at the end of the seven week infestation period.

\section{Experimental design and statistical analysis}

The experiment was set up in completely randomized design. Data were subjected to analysis of variance and significant means were separated using Studentized Neuman Keuls (SNK) test at $5 \%$ probability level.

\section{Results}

Mortality of $T$. castaneum and

\section{S. zeamais on dried okra}

The results show that as WAI increased, mortality rate increased. At 24 WAI, highest mortality was observed in the experimental set up with ten $T$. castaneum adult which was followed by experimental set up with 20 adults of 
T. castaneum at 4-5 WAI. Percentage mortality (93.32\%) observed when ten T. castaneum adults were introduced was significantly $(p<0.05)$ higher than
$61.67 \%$ adult mortality observed when $20 \mathrm{~S}$. zeamais adults were introduced (Table 1).

Table 1. Percentage mortality of $S$. zeamais and T. castaneum in stored dried okra fruits.

\begin{tabular}{|c|c|c|c|c|c|c|c|}
\hline \multicolumn{8}{|c|}{ Weeks after infestation } \\
\hline Insects species & $\begin{array}{c}\text { Insect } \\
\text { population }\end{array}$ & 1 & 2 & 3 & 4 & 5 & 6 \\
\hline T. castaneum & 5 & $20.00 \pm 0.00$ & $33.33 \pm 6.67$ & $46.67 \pm 13.33$ & $73.33 \pm 6.67 \mathrm{ab}$ & $73.33 \pm 6.67 \mathrm{ab}$ & $80.00 \pm 0.00$ \\
\hline T. castaneum & 10 & $13.33 \pm 3.33$ & $50.00 \pm 5.77$ & $73.33 \pm 6.6 ?$ & $93.33 \pm 6.67 \mathrm{~b}$ & $93.33 \pm 6.67 \mathrm{~b}$ & $93.33 \pm 6.67$ \\
\hline T. castaneum & 20 & $6.67 \pm 1.67$ & $35.00 \pm 5.00$ & $63.33 \pm 8.82$ & $76.67 \pm 6.67 \mathrm{~b}$ & $83.33 \pm 7.27 \mathrm{ab}$ & $86.67 \pm 8.33$ \\
\hline S. zeamais & 5 & $20.00 \pm 0.00$ & $33.33 \pm 6.67$ & $46.67 \pm 13.33$ & $73.33 \pm 6.67 \mathrm{ab}$ & $73.33 \pm 6.67 \mathrm{ab}$ & $80.00 \pm 0.00$ \\
\hline S. zeamais & 10 & $13.33 \pm 3.33$ & $36.67 \pm 3.33$ & $56.67 \pm 3.33$ & $73.33 \pm 3.33 \mathrm{ab}$ & $83.33 \pm 3.33 \mathrm{ab}$ & $86.67 \pm 6.67$ \\
\hline S. zeamais & 20 & $21.64 \pm 10.14$ & $26.67 \pm 1.67$ & $40.00 \pm 2.91$ & $51.67 \pm 4,41 \mathrm{a}$ & $61.67 \pm 4.41 \mathrm{a}$ & $71.67 \pm 4.41$ \\
\hline ANOVA & - & $\mathrm{df}=5,15$ & $\mathrm{df}=5,15$ & $\mathrm{df}=5,15$ & $\mathrm{df}=5,15$ & $\mathrm{df}=5,15$ & $\mathrm{df}=5,15$ \\
\hline RESULTS & & $F=1.41$ & $F=3.12$ & $F=2.73$ & $F=6.71$ & $\mathrm{~F}=4.18$ & $F=1.90$ \\
\hline & & $\mathrm{p}=0.30$ & $\mathrm{p}=0.07$ & $\mathrm{p}=0.09$ & $p<0.007$ & $\mathrm{p}<0.03$ & $\mathrm{p}=0.20$ \\
\hline
\end{tabular}

Data are means of three replicates \pm standard error (SE). Values with different alphabets along the column are significantly $(\mathrm{P}<0.05)$ different using Studentized Neuman Keuls (SNK) Test.

\section{Weight loss of dried okra fruits due to T.castaneum and S. zeamais feeding}

The results show that as the initial insect population increased, weight loss of okra increased (Table 2). It also revealed that as WAI increased, the weight loss of okra fruit increased. Infestation of dried okra fruit with 20 adult insects regardless of the species caused significantly higher percentage weight loss than what was observed when okra was infested with five insects. Percentage weight loss for both insects ranged from $0.04 \%-0.18 \%$, 0.07\%-0.21\%, $\quad 0.08 \%-0.22 \%$, $0.07 \%-0.22 \%, \quad 0.11 \%-0.22 \%$, and 0.12 $0.23 \%$ for $1,2,3,4,5$ and $6 \mathrm{WAI}$, respectively.

Table 2. Effect of $S$. zeamais and T. castaneum infestation on percentage weight loss of dried okra fruit.

\begin{tabular}{|c|c|c|c|c|c|c|c|}
\hline \multicolumn{8}{|c|}{ Weeks after infestation } \\
\hline Insects species & $\begin{array}{c}\text { Insect } \\
\text { population }\end{array}$ & 1 & 2 & 3 & 4 & 5 & 6 \\
\hline T. castaneum & 0 & $0.00 \pm 0.00 \mathrm{a}$ & $0.00 \pm 0.00 \mathrm{a}$ & $0.00 \pm 0.00 \mathrm{a}$ & $0.00 \pm 0.00 \mathrm{a}$ & $0.00 \pm 0.00 \mathrm{a}$ & $0.00 \pm 0.00 \mathrm{a}$ \\
\hline T. castaneum & 5 & $0.04 \pm 0.01 \mathrm{a}$ & $0.07 \pm 0.01 \mathrm{~b}$ & $0.08 \pm 0.01 b$ & $0.11 \pm 0.01 \mathrm{~b}$ & $0.011 \pm 0.01 b$ & $0.12 \pm 0.01 b$ \\
\hline T. castaneum & 10 & $0.07 \pm 0.01 b$ & $0.09 \pm 0.02 b$ & $0.13 \pm 0.03 \mathrm{~b}$ & $0.15 \pm 0.03 \mathrm{c}$ & $0.015 \pm 0.03 c$ & $0.15 \pm 0.03 b c$ \\
\hline T. castaneum & 20 & $0.11 \pm 0.02 \mathrm{~b}$ & $0.15 \pm 0.03 \mathrm{c}$ & $0.17 \pm 0.03 c$ & $0.20 \pm 0.03 \mathrm{~cd}$ & $0.20=0.02 \mathrm{~d}$ & $0.22 \pm 0.01 \mathrm{~d}$ \\
\hline S. zeamais & 0 & $0.00 \pm 0.00 \mathrm{a}$ & $0.00 \pm 0.00 \mathrm{a}$ & $0.00 \pm 0.00 \mathrm{a}$ & $0.00 \pm 0.00 \mathrm{a}$ & $0.00 \pm 0.00 \mathrm{a}$ & $0.00 \pm 0.00 \mathrm{a}$ \\
\hline S. zeamais & 5 & $0.05 \pm 0.01 \mathrm{a}$ & $0.07 \pm 0.01 \mathrm{~b}$ & $0.06 \pm 0.02 \mathrm{ab}$ & $0.07 \pm 0.02 \mathrm{~b}$ & $0.13 \pm 0.05 b c$ & $0.07 \pm 0.02 b$ \\
\hline S. zeamais & 10 & $0.12 \pm 0.01 b$ & $0.16 \pm 0.02 \mathrm{c}$ & $0.13 \pm 0.04 \mathrm{~b}$ & $0.15 \pm 0.04 \mathrm{c}$ & $0.13 \pm 0.04 \mathrm{bc}$ & $0.14 \pm 0.014 b c$ \\
\hline S. zeamais & 20 & $0.18 \pm 0.01 \mathrm{c}$ & $0.21 \pm 0.01 \mathrm{~d}$ & $0.22 \pm 0.01 \mathrm{~d}$ & $0.22 \pm 0.01 \mathrm{~d}$ & $0.22 \pm 0.01 \mathrm{~d}$ & $0.23 \pm 0.01 \mathrm{~d}$ \\
\hline $\begin{array}{l}\text { ANOVA } \\
\text { RESULTS }\end{array}$ & $\cdot$ & $\begin{array}{l}\text { df }=7,21 \\
F=24.87 \\
p<0.0001\end{array}$ & $\begin{array}{l}\mathrm{df}=7,21 \\
\mathrm{~F}=18.63 \\
\mathrm{p}<0.0001\end{array}$ & $\begin{array}{l}\mathrm{df}=7,21 \\
\mathrm{~F}=8.99 \\
\mathrm{p}<0.0001\end{array}$ & $\begin{array}{l}\text { df }=7,21 \\
F=12.75 \\
p<0.0001\end{array}$ & $\begin{array}{l}\text { df }=7,21 \\
F=5.95 \\
p<0.0001\end{array}$ & $\begin{array}{l}\mathrm{df}=7,21 \\
\mathrm{~F}=15.90 \\
\mathrm{p}<0.0001\end{array}$ \\
\hline
\end{tabular}

Data are means of three replicates \pm standard error (SE). Values with different alphabets along the column are significantly $(\mathrm{P}<0.05)$ different using Studentized Neuman Keuls (SNK) Test. 
Effect of S. zeamais and T. castaneum infestation on proximate composition of dried okra fruit

Percentage moisture decreased from $13.64 \%$ at the beginning of the experiment to $11.51 \%-11.91 \%$ at the end. Insect levels had no significant effect on moisture content of dried okra fruit (Table 3). Protein content of stored okra fruit was not affected by the treatment, but slightly increased from $14.07 \%$ at the beginning of the experiment to $14.50 \%$ $15.31 \%$ at the end of the experiment. Ash content at the end of the experiment significantly increased compared with the initial value at the beginning of the experiment. Fat content was not affected by insect level or storage period but slightly increased compared with the level at the beginning of the experiment. Introduction of insect significantly increased crude fibre of stored okra fruit with $13.63 \%-14.62 \%$ being significantly higher than the value for okra at the beginning of the experiment (9.12\%). The initial level of carbohydrate $(52.50 \%)$ was significantly higher than the level $(46.60 \%)$ in the un-infested okra after the experiment. which indicates that storage period but not insect infestation had deleterious effect on the carbohydrate level (Table 3).

Table 3. Proximate analysis (mg/100 mg) of stored dried okra fruit exposed to S. zeamais and T. castaneum infestation after 6 week storage.

\begin{tabular}{|l|c|c|c|c|c|c|c|}
\hline \multicolumn{9}{|c|}{ Proximate component } \\
\hline Treatment & $\begin{array}{c}\text { Initial } \\
\text { population }\end{array}$ & Moisture & Protein & Ash & Fat & Crude fibre & Carbohydrate \\
\hline $\begin{array}{l}\text { No insect at the beginning of } \\
\text { experiment }\end{array}$ & - & $13.64 \pm 0.30$ & $14.07 \pm 0.17$ & $9.61 \pm 0.22 \mathrm{a}$ & $10.08 \pm 0.73$ & $9.12 \pm 0.31 \mathrm{a}$ & $52.50 \pm 0.34 \mathrm{~d}$ \\
\hline $\begin{array}{l}\text { No insect at the end of } \\
\text { experiment }\end{array}$ & - & $11.51 \pm 0.21$ & $15.31 \pm 0.27$ & $11.44 \pm 0.22 \mathrm{~cd}$ & $11.99 \pm 0.11$ & $9.18 \pm 0.86 \mathrm{a}$ & $46.60 \pm 0.51 \mathrm{abc}$ \\
\hline S. zeamais & 5 & $11.80 \pm 0.11$ & $15.22 \pm 0.30$ & $11.71 \pm 0.31 \mathrm{~d}$ & $11.72 \pm 0.03$ & $14.30 \pm 0.30 \mathrm{~d}$ & $45.90 \pm 0.11 \mathrm{a}$ \\
\hline S. zeamais & 10 & $11.52 \pm 0.52$ & $14.90 \pm 0.50$ & $11.60 \pm 0.44 \mathrm{~cd}$ & $11.61 \pm 0.09$ & $14.33 \pm 0.30 \mathrm{~d}$ & $46.31 \pm 0.20 \mathrm{ab}$ \\
\hline S. zeamais & 20 & $11.65 \pm 0.35$ & $15.08 \pm 0.50$ & $11.50 \pm 0.32 \mathrm{~cd}$ & $11.60 \pm 0.00$ & $14.40 \pm 0.00 \mathrm{~d}$ & $46.70 \pm 0.70 \mathrm{abc}$ \\
\hline T. castaneum & 5 & $11.80 \pm 0.60$ & $14.70 \pm 0.50$ & $11.20 \pm 0.30 \mathrm{~cd}$ & $12.40 \pm 0.12$ & $14.30 \pm 0.30 \mathrm{~d}$ & $46.84 \pm 0.40 \mathrm{abc}$ \\
\hline T. castaneum & 10 & $11.52 \pm 0.40$ & $14.50 \pm 0.20$ & $10.62 \pm 0.30 \mathrm{c}$ & $11.68 \pm 0.32$ & $14.62 \pm 0.80 \mathrm{e}$ & $47.61 \pm 0.52 \mathrm{abc}$ \\
\hline T. castaneum & 20 & $11.91 \pm 0.90$ & $15.11 \pm 0.20$ & $10.10 \pm 0.12 \mathrm{c}$ & $11.60 \pm 0.07$ & $13.93 \pm 0.14 \mathrm{~b}$ & $47.22 \pm 0.14 \mathrm{abc}$ \\
\hline $\begin{array}{l}\text { ANOVA } \\
\text { RESULTS }\end{array}$ & - & $\begin{array}{l}\mathrm{df}=7,15 \\
\mathrm{~F}=1.277 \\
\mathrm{p}<0.367\end{array}$ & $\begin{array}{l}\mathrm{df}=7,15 \\
\mathrm{~F}=1.085 \\
\mathrm{p}=0.451\end{array}$ & $\begin{array}{l}\mathrm{df}=7,15 \\
\mathrm{~F}=18.05 \\
\mathrm{p}<0.0001\end{array}$ & $\begin{array}{l}\mathrm{df}=7,15 \\
\mathrm{~F}=2.43 \\
\mathrm{p}=0.119\end{array}$ & $\begin{array}{l}\mathrm{df}=7,15 \\
\mathrm{~F}=74.53 \\
\mathrm{p}<0.0001\end{array}$ & $\begin{array}{l}\mathrm{df}=7,15 \\
\mathrm{~F}=41.49 \\
\mathrm{p}<0.0001\end{array}$ \\
\hline
\end{tabular}

Data are means of two replicates \pm standard error (SE). Values with different alphabets along the column are significantly $(\mathrm{P}<0.05)$ different using Studentized Neuman Keuls (SNK) Test.

\section{Discussion}

The growing awareness of postharvest losses with intensive use of management practice has led to the interest in the study of damage potentials of insect pests and the stage at which they cause the damage. One of the means of preserving okra fruit in the developing countries is drying. From the results of this study, there was significant difference in the mortality observed in the treatments. The two insects caused significant percentage weight loss due to their feeding on the dried stored okra fruit. The high percentage mortality and lack of any immature stage of the insects indicates that dried okra, unlike cereals, neither supported longevity or reproduction of the insects. In an early study by Babarinde et al. (2008b), $S$. zeamais was observed to feed on some dried vegetables but did not utilize them for its reproduction.

The fact that okra fruit weight was significantly reduced by the highest experimented threshold of the two insect species indicates that the insects utilized dried okra fruit for food. It was observed that regardless of the level of insect infestation, significant weight loss was observed at six week storage period 
compared with the un-infested control. The range of the weight loss observed in this study was however low, compared with $38.3 \%$ and $1.9 \%$ reported by Padin et al. (2002) in wheat infested by $S$. oryzea and T. castaneum, respectively. In their study on infestation of dried tomato fruit by L. serricorene, Babarinde et al. (2008a) observed that there was a weight loss of $0.54 \mathrm{~g}$ out of the initial weight of $25 \mathrm{~g}$ corresponding to $2.16 \%$ after two month storage period. Babarinde et al. (2010b) had previously reported that percentage weight loss of plantain Musa sapientum L. (Zingiberales: Musaceae) infested with T.castaneum was dependent of insect thresho; d and storage duration and ranged from 0.3$1.9 \%$. The reasons for the comparatively low weight loss due to the insects' infestation could be attributable to the morphological form of the dried okra (Plate 1c). S. zeamais is a granivorous species which does well on grains or other intact food materials for both longevity and reproduction than lose or perforated produce.

At the end of the experimental period, moisture content slightly reduced in uninfested samples, compared with the moisture content at the beginning of the experiment. The slight but nonsignificant increase in protein, ash, fat and crude fibre at the end of the experiment in uninfested okra samples could be attributable to the loss in moisture in storage; since the results of the proximate analysis are presented in percentage weight per weight. Crude fibre was the only proximate component that significantly increased with insect infestation. Our result agrees with Bamaiyi et al. (2006) who reported that Crude fibre of bruchid-infested cowpea increased with storage period. In another study by Danjuma et al. (2009), Crude fibre of stored maize grains increased due to the infestation by $S$. zeamais. It is therefore possible be that insects feed on other nutritional components of stored produce at the expense of the lesspreferred dietary fibre.
In conclusion, the findings from this study show that the pests caused significant weight loss after seven week infestation period. Although going by the percentage weight loss $(0.04 \%-0.23 \%)$ in the short time storage, the pests seem not to pose serious threat to stored okra; it can be a serious concern if the storage period is prolonged and the tendency of cross-infestation is heightened. Therefore, it is recommended that dried okra fruit should be stored in insectproof storage facilities.

\section{Conflicts of interest}

Authors declare that they have no conflict of interests.

\section{References}

Adetuyi, F. O.; Osagie, A. U.; Adekunle, A. T. Efect of postharvest storage techniques on the nutritional properties of Benin indigenous okra (Abelmoschus esculentus (L.) Moench). Pakistan Journal of Nutrition, v. 7, no. 5, p. 652-657, 2008. https://doi.org/10.3923/pjn. 2008.652.657

Akanbi, W. B.; Toogun, A. O.; Adeniran, J. A.; Ilupeju, E. A. O. Growth, dry matter and fruit yield components of okra under organic and inorganic sources of nutrients. AmericaEurasian Journal of Sustainable Agriculture, v. 4, no. 1, p.1-13, 2010. Available from: <http://www.aensiweb.net/ AENSIWEB/aejsa/aejsa/2010/1-13.pdf>.

Accessed on: Oct. 31, 2017.

Akande, M. O.; Oluwatoyinbo, F. I.; Makinde, E. A.; Adepoju, A. S.; Adepoju, I. S. Response of okra to organic and inorganic fertilization. Nature Science, v. 8, no. 11, p. 261-266, 2010. <http://www.sciencepub.net/nature/ ns0811/33_3782ns0811_261_266.pdf>.

Accessed on: Oct. 31, 2017.

Akinyele, B. O.; Temikotan, T. Effect of variation in soil tecture on the vegetative and pod characteristics of okra (Abelmoschus esculentus (L.) Moench). International Journal of Agricultural Research, v. 2, p. 165-169, 2007. http://doi.org/10.3923/ ijar.2007.165.169

AOAC - AOAC International. Official methods of analysis. 17. ed. Washington: AOAC International, 2003. 
Babarinde, S. A.; Adebayo, T. A.; Pitan, 0. 0. R.; Folorunsho, J. T. Host influence on population growth and damage by cigarette beetle (Lasioderma serricorne Fabricius) in Ogbomoso, Nigeria. Crop Research, v. 35, no. 3, p. 268-272, 2008a.

Babarinde, S. A.; Sosina, A.; Oyeyiola, E. I. Susceptibility of the selected crops in storage to Sitophilus zeamais Motschulsky in Southwestern Nigeria. Journal of Plant Protection Research, v. 48, no. 4, p. 541550, 2008b. https://dx.doi.org/10.2478/ v10045-009-0003-z

Babarinde, S. A.; Babarinde, G. O.; Olasesan, O.A. First report of infestation of stored plantain chips by Trogoderma granarium Everts (Coleoptera: Dermestidae) in Southwestern Nigeria. Tree and Forestry Science and Biotechnology, v. 4, special issue 2, p. 35-38, 2010a.

Babarinde, S. A.; Babarinde, G. O.; Olasesan, 0. A. Physical and biophysical deterioration of stored plantain chips (Musa sapientum L.) due to infestation of Tribolium castaneum Herbst (Coleoptera: Tenebrionidae). Journal of Plant Protection Research, v. 50, no. 3, p. 302-306, 2010b. https://doi.org/ 10.2478/v10045-010-0052-y

Babarinde, G. O.; Babarinde, S. A.; Ogunsola, S. O. Effect of maize weevil (Sitophilus zeamais Motschulsky 1855) infestation on the quality of three commercial pastas. Food Science and Quality Management, v. 21, p.1-11, 2013a. Available from: <http://iiste.org/Journals/index.php/FSQM/ article/view/8817/8865>. Accessed on: Oct. 31, 2017.

Babarinde, S. A.; Babarinde, G. O.; Odewole, A. F.; Alagbe, O. O. Effect of the prevalent insect species of yam chips on consumers' acceptability of yam paste. Agricultura Tropica et Subtropica, v. 43 no. 6, p. 97-101, 2013b. https://doi.org/10.2478/ats-20130017

Danjumma, B. J.; Majeed, Q.; Abubakar, U.; Ibrahim, N. D. Effect of pre-treatment with plant powders on the nutrient composition of maize grain Zea mays infested by weevil Sitophilus zeamais Motsch. Nigerian Journal of Basic and Applied Science, v. 17, no. 2, p. 211-217, 2009. https://doi.org/10.4314/ njbas. v17i2.49898

Ekoja, E. E.; Pitan, O. O. R.; Atayese, M. O. Physiological response of okra to flea beetle herbivory as measured by leaf loss, chlorophyll disruption, and dry matter yield. International Journal of Vegetable Science, v. 18, no. 2, p.171-181, 2012. https://doi.org/10.1080/19315260.2011.59 8224

Farinde, A. J.; Owolarafe, O. K.; Ogungbemi, 0. I. An overview of production, processing and marketing and utilization of okra in Egbedore Local Givernment Area of Osun, Nigeria. Journal of Agricultural Science, v. 9, p. 1-12, 2007. Available from: <http://www.cigrjournal.org/index.php/Ejo unral/article/viewFile/959/1119>. Accessed on: Oct. 31, 2017.

Lamont Jr., W. J. Okra: a versatile vegetable crop. Horticultural Technology, v. 9, no. 2, p.179-184, $1997 . \quad$ Available from: <http://horttech.ashspublications.org/conte nt/9/2/179.full.pdf $>$. Accessed on: Oct. 31, 2017.

Odeyemi, O. O.; Oyedare, B. M.; Ashamo, M. 0. Resistance of seven biscuit types to infestation by Tribolium castaneum (Herbst) (Coleoptera: Tenebrionidae). Zoological Research, v. 26, no. 3, p. 300-304, 2005. Available from: <http://www.bioline.org.br/ pdf?zr05012>. Accessed on: Oct. 31, 2017.

Owolarafe, O. K.; Shotonde, H. O. Some physical properties of fresh okra fruit. Journal of Food Engineering, v. 63, p. 299302, 2004. https://doi.org/10.1016/ j.jfoodeng.2003.08.002

Padin, S.; Bello, G. D.; Fabrizio, M. Grain loss caused by Tribolium castaneum, Sitophilus oryzae and Acanthoscelides obtectus in stored durum wheat and bean treated with Beauveria bassiana. Journal of Stored Product Research, v. 38, no. 1, p.69-74, $2002 . \quad$ https://doi.org/10.1016/S0022474X(00)00046-1

Pungitore, C. R.; García, M.; Gianello, J. C.; Tonn, C. E.; Sosa, M. E. Lethal and sublethal effects of triterpenes from Junellia aspera (Verbenaceae) on the grain storage insect Tribolium castaneum (Coleoptera: Tenebrionidae). Revista de la Sociedad Entomológica Argentina, v. 64, no. 1/2, p. 45-51, 2005. Available from: <http://www.scielo.org.ar/pdf/rsea/v64n12/v64n1-2a10.pdf $>$. Accessed on: 0ct. 31, 2017.

Trematerra, P. Preference of Sitophilus zeamais to different types of Italian commercial rice and cereal pasta. Bulletin of Insectology, v. 62, no. 1, p. 103-106, 2009. 
Available from: <http://www.bulletin ofinsectology.org/pdfarticles/vol62-2009103-106trematerra.pdf>. Accessed on: Oct. 31, 2017.

Tremattera, P.; Savoldelli, S. Pasta preference and ability to penetrate through packaging of Sitophilus zeamais Motschulsky (Coleoptera: Dryophthoridae). Journal of Stored Product Research, v. 59, p. 126-132, 2014. https://dx.doi.org/10.1016/j.jspr.2014.06.00 8 